\title{
Ontogeny and embryonic description of Betta splendens, Perciformes (Regan, 1910)
}

\author{
Ontogenia e descrição embrionária em "Betta splendens"
}

\author{
DUARTE, Shaytner Campos ${ }^{1 *}$; VASCONCELLOS, Breno de Faria e ${ }^{2}$; VIDAL \\ JÚNIOR, Manuel Vazquez ; FERREIRA, Andre Veloso ${ }^{1}$; MATTOS, Douglas da \\ Cruz ${ }^{1}$; BRANCO, Allex Trindade ${ }^{1}$
}

\begin{abstract}
${ }^{1}$ Universidade Estadual do Norte Fluminense Darcy Ribeiro, Centro de Ciências e Tecnologias Agropecuárias, Laboratório de Zootecnia e Nutrição Animal, Campos dos Goytacazes, Rio de Janeiro, Brasil.

${ }^{2}$ Pontifícia Universidade Católica de Goiás, Departamento de Zootecnia, Goiânia, Goiás, Brasil.

*Endereço para correspondência: shaytner@gmail.com
\end{abstract}

\section{SUMMARY}

Ontogeny process comprises the embryo development from the moment of fecundation, through embryonic development phase, until hatching or later phases. The study of embryogenesis is an important tool for growth study of the species within their natural environment. The present work observed and registered the main stages of Betta splendens embryonic development, one of the most promising ornamental species mostly because of the increasing commercial interest, to describe the initial ontogeny and thus contribute for a better understanding about the biology of this species. It was possible to observe that as the embryonic time passes, there was a decrease in yolk height and then at its length, mainly at the final phases of embryonic period. Newly hatched larvae did not use feed from exogenous source. The embryo of B. splendens presented embryonic development phases similar to the observed for other teleostei species. The 1 st cell division/blastula was observed at 1 HPF (HourPost-Fertilization) until the 7.5 HPF; the gastrula period was observed starting at $8.5 \mathrm{HPF}$ until 14.5 HPF; the organogenesis period was from $15 \mathrm{HPF}$ until the hatching moment, at 38 HPF.

Keywords: embryo, ornamental, siamese fighting-fish, yolk.

\section{RESUMO}

O processo de ontogenia pode ser descrito como o desenvolvimento do embrião desde o momento da fecundação, passando pela fase de desenvolvimento embrionário, até a eclosão ou fases posteriores. $\mathrm{O}$ estudo da embriogênese de uma espécie é de grande importância, por ser uma ferramenta útil no estudo do crescimento de espécies em seu ambiente natural. O presente trabalho teve por objetivo descrever a ontogenia inicial em embriões da espécie Betta splendens, uma das espécies ornamentais que mais se destaca devido ao grande interesse comercial, mediante a observação e registro dos principais estádios do desenvolvimento embrionário, contribuindo dessa forma para um melhor conhecimento da biologia da espécie. Foi possível observar que com o desenvolvimento embrionário, houve uma diminuição no volume do vitelo principalmente nas fases finais desse período. As larvas recém eclodidas observadas no presente estudo não utilizaram alimentos de fonte exógena. $\mathrm{O}$ embrião de $B$. splendens apresentou fases de desenvolvimento embrionário semelhantes aquelas observadas em outras espécies de teleósteos. A $1^{\mathrm{a}}$. divisão celular/blástula foi observada à 1 HPF (Hora Pós-Fecundação) até as $7.5 \mathrm{HPF}$; o período de gástrula foi observado a partir de $8.5 \mathrm{HPF}$ até 14.5 HPF; o período de organogênese foi de 15 HPF até o momento da eclosão, às $38 \mathrm{HPF}$.

Palavras-chave: embrião, ornamental, peixede-briga, vitelo. 


\section{INTRODUCTION}

Initial phases of aquaculture are characterized by high mortality, mostly due to physicochemical variations in water, what affects commercial production of fish. Information related to morphological development and morphometrical parameters, growth patterns and fish behavior are essential to understand the changes on physiological and ecological demands of each species and the factors that affect its performance (KOVAC \& COPP, 1999; MACIEL et al., 2010; PEREZ-CASANOVA et al., 2006).

Aquaculture is an activity that is expanding around the world as well as the ornamental fish production. Betta splendens (Belontiidae family, Anabantoidei suborder) a native species from southeast Asia, popularly known in Brazil as 'beta' or 'fight-fish', is a highlight of ornamental fish market due its beauty, variety of colors, and resistance (VERBEEK et al., 2007). In Brazil, production of betta overpasses 200,000 units/month (FARIA et al., 2006), and is one of the five ornamental species most imported by USA; thus, new technologies for management are important in order to satisfy this market (CHAPMAN et al., 1997, FERREIRA et al., 2009).

Brazil is a country with high potential for the development of ornamental aquaculture, and the implementation of this activity in sustainable way is surely a great challenge (TONINI et al., 2012). Tropical climate, the abundance of good water and low cost of the land are favorable to the expansion of betta production in most states (LUZ \& ZANIBONI FILHO, 2002). Its natural habitat presents a small water column with low concentration of oxygen, which explain the adaptation to conditions that would be non-favorable to other species (PAMPLONA, et al., 2004; FARIA et al., 2006).

Description and knowledge of embryonic events of teleostei fish supply information to avoid malformation and high mortality, enhancing the management of incubation. Ontogeny of fish has been the scope for researchers due to the important contribution to the knowledge of initial phases, biology and taxonomy of species, and thus improving commercial larviculture, as well as the performance of fishculture ( FERREIRA et al., 2009; MACIEL et al., 2010).

There is little information about embryonic development of ornamental fish in scientific literature, especially about B. splendens (GROTH, 1970). This research aims to contribute to identify, through ontogeny, the viable eggs and larvae produced in captivity. Monitoring and observation of spawning and initial development can maximize the development of B. splendens.

\section{MATERIAL AND METHODS}

Embryogenesis was observed from eggs naturally spawned of $B$. splendens, common variety from the aquaculture section of Laboratório de Zootecnia e Nutrição Animal from Centro de Ciências e Tecnologias Agropecuárias, Universidade Estadual do Norte Fluminense Darcy Ribeiro - UENF.

Six couples were placed in one of six experimental aquariums for breeding. Aquariums were made of white polyethylene with $15 \mathrm{~L}$ capacity. In order to stimulate reproduction, female was kept within a transparent cylindrical recipient, allowing visual contact but separated from male until the moment of breeding. Couple was fed with commercial feed $(42 \%$ crude 
protein) and with artemias and daphnias during 48 hours. Eichornia crassipes (water hyacinth) leaves or a square of polystyrene $(5 \times 5 \mathrm{~cm})$ were placed as spawning support to assist the male when building the bubble nest, the place where fecundated eggs are kept.

Spawning occurred spontaneously and eggs were collected from nests with a fine sieve, grouped into a 40L aquarium filled with water from supplying system of the laboratory.

The first spawn that was collected contained approximately 400 eggs and the second, approximately 200 with an interval of 15 minutes. These spawns were stored into the experimental aquarium, assembling groups of eggs to be used. The objective of gathering two spawns was to increase the amount of eggs in the end, because a lost is expected during eggs management during experiment. Spawns were placed and kept inside experimental aquariums at fluctuating sieves during all incubation period at $28^{\circ} \mathrm{C}$ until hatching. Samples from each sieve contained 10 (ten) eggs, and were analyzed at light microscope with $25 \mathrm{x}$ or $100 \mathrm{x}$ increase to characterize and identify embryonic stage.

Hours-post-fertilization (HPF) and hours-degrees-post-fertilization (HDPF) were used to measure time and correlate the morphophysiological events and the yolk resorption. HPF was measured counting the time between fecundation, corresponding to zero hour (H0), to spawn. HDPF was calculated with HPF multiplied by the temperature of the water from experiment at given time.

At each observation the eggs were collected randomly from sieve, placed on glass slides, observed in optical microscope $(25 \mathrm{x}$ and 100x) and photographed with digital camera DSC P-200, connected to trinocular tube of optical microscope. At the end of each observation, eggs returned to respective sieves.

Observation of external aspect of embryos was made at each half an hour during embryonic period 0 until 30hpf, and at each $1 \mathrm{~h}$ after $30 \mathrm{hpf}$ until hatching moment, that happened around 38 hours post fertilization, totaling 69 observations. Eggs height, from animal pole to the opposite extreme, and width (longitudinal axis) were measured with a micrometer scale ocular. 10 eggs were observed and measured at each 4 hours interval, totaling 9 replicates, assembling 90 measurements.

Each embryonic development stage was identified from the moment that most eggs reached that stage. Pictures from embryonic stages were documented with micrographics.

Embryonic developments were classified based on morphological characteristics and followed the definitions and criterions of the methodology used for brycon (Brycon insignis) by Souza (2004), Fujimoto et al. (2004), Fujimoto et al. (2006) and Ferreira et al. (2009). According to them, the cleavage period lasted from 2 blastomeres until 64 blastomeres. When 128 blastomeres were formed, the blastula period began. Later, the description of gastrula (period when the blastoderm embraces the yolk) was made and then the morphophysiological events of the organogenesis period were described. Definitions for blastula and gastrula stages were adapted from Blaxter (1998) and Fujimoto et al. (2006).

After hatching, the newly hatched larvae (larvae $\mathrm{H} 0$, hatching moment) were visually characterized according to swimming ability. Later, total width, larvae height, yolk sac width and height were estimated from 11 individuals. The number of somites was also counted.

Water temperature of matrix aquariums and incubators were kept within 
minimum variation and controlled by heating device coupled with automatic thermostat. Temperature was measured at the moment of eggs collection from matrix aquariums and at each moment of observation in the incubator aquariums. These measurements were taken using thermometer of mercury bulb.

Mean values and standard deviation $(\mathrm{P}<0.05)$ taken for physicochemical parameters of water from incubators, during experimental period, were 27.98 $\pm 0.08^{\circ} \mathrm{C}$ for temperature, $7.43 \pm 0.46$ for $\mathrm{pH}, 6.30 \pm 0.53 \mu \mathrm{S}$ for conductance and $4.6 \pm 0.41 \mathrm{mg} / \mathrm{L}$ for dissolved oxygen. The water $\mathrm{pH}$ was verified at each 6 hours during the observation, using a $\mathrm{pH}$ electronic measurer. Dissolved oxygen level of water from incubators was monitored with a digital oximeter sensor for aquariums, during all experimental period, 4 times a day, at 00:00h, 06:00h, 12:00h and 18:00h.

\section{RESULTS AND DISCUSSION}

B. splendens eggs presented spherical shape, with a little translucent corium and a vitelline vesicle. Diameter of eggs recently fecundated varied from 0.6210 to $0.7200 \mathrm{~mm}$, with $0.6506 \mathrm{~mm}$ in average. Corium was a little stiffed and the texture was similar to small "gelatin spheres". Eggs (Figure 1) contained several oil drops of different sizes, initially spread at the periphery of the vitelline vesicle.
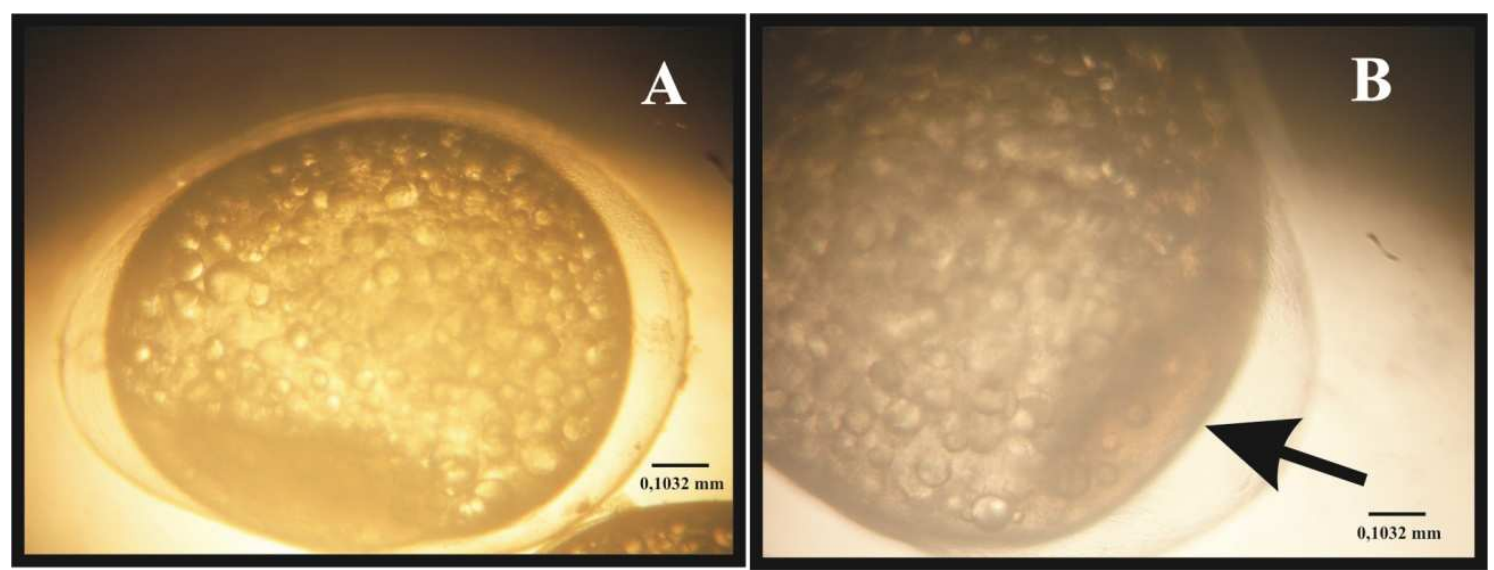

Figure 1. Internal and external observation of $B$. splendens eggs recently fertilized. A: drops of oil; B: animal pole (pointed by the black arrow).

Embryonic development (Tables 1 and 2) of B. splendens presented five well defined periods, which were classified in cleavage, blastula, segmentation, organogenesis and pre-hatching (REID \& HOLDWAY, 1995; HUMPHREY et al. 2003; FUJIMOTO et al., 2006).

The first modifications observed in eggs were cytoplasm movement towards animal pole and formation of blastoderm 30 minutes after fertilization. Cleavage of $B$. splendens embryos was meroblastic, similar to other teleostei. Blastomeres were initially divided at each 30 minutes (average).

During the organogenesis period, tissues and organs differentiates. Organogenesis began once gastrula period ended and could be observed until pre-hatching moment. The events observed within this period were 
Rev. Bras. Saúde Prod. Anim., Salvador, v.13, n.3, p.xxx-xxx jul./set., 2012 http://www.rbspa.ufba.br ISSN 15199940

differentiation of primordial optic and hearing organs, pigmentation and the beginning of heart beats, among others (Table 3). These characteristics are important and very useful in morphophysiological description and identification of teleosts development stages (HUMPHREY et al., 2003; FUJIMOTO et al., 2006; HANIFFA et al., 2007).

Betta splendens embryonic development presents similar phases to other theleostei species. In comparison to Groth (1970), the description of the observed events was very similar, being the main difference the time, in HPF, of the moments in such events occurred. These variations could be resulted of the difference in temperature between the applied methodologies.

Eggs of $B$. splendens presented smaller diameters than the eggs from Melanotaenia splendida inornata with $0.8800 \mathrm{~mm}$ in average, and Melataenia nigrans $1.0500 \mathrm{~mm} \quad$ (REID \& HOLDWAY, 1995), and Glossolepis incisus $0.9000 \mathrm{~mm}$ to $1.1000 \mathrm{~mm}$ (FERREIRA et al., 2009).

Table 1. Cleavage period: roll of embryonic stages/events of Betta splendens observed until 7.5 HPF of the experiment

\begin{tabular}{lcc}
\hline \multicolumn{1}{c}{ Stage/Events } & HPF & HGPF ${ }^{\circ} \mathrm{C}$ \\
\hline Fertilization & 0 & 0 \\
Animal pole $1^{\text {st }}$ division & 1.0 & 28.0 \\
2 blastomeres & 1.5 & 42.0 \\
4 blastomeres & 2.0 & 56.0 \\
8 blastomeres & 2.5 & 70.0 \\
16 blastomeres & 3.0 & 84.0 \\
32 blastomeres & 3.5 & 98.0 \\
64 blastomeres & 4.0 & 112.0 \\
128 blastomeres & 4.5 & 126.0 \\
$256-1024$ blastomeres & $5.0-6.5$ & $140.0-182.0$ \\
2048 blastomeros & 7.0 & 196.0 \\
Spherical & 7.5 & 210.0 \\
\hline
\end{tabular}

*Hours-post-fertilization (HPF); *Hours-degrees-post-fertilization (HGPF)

Table 2. Gastrula period: embryonic stages/events of Betta splendens observed from 8.5 until 14.5 HPF of the experiment

\begin{tabular}{lcc}
\hline Stages/Events & HPF & HGPF $^{\circ} \mathrm{C}$ \\
\hline Gastrula $10 \%$ & 8.5 & 238.0 \\
Gastrula 50\% & 11.0 & 308.0 \\
Gastrula 70\% & 13.0 & 364.0 \\
Gastrula 80\% & 14.0 & 392.0 \\
Blastopore closing & 14.5 & 406.0 \\
\hline
\end{tabular}


Rev. Bras. Saúde Prod. Anim., Salvador, v.13, n.3, p.xxx-xxx jul./set., 2012 http://www.rbspa.ufba.br ISSN 15199940

Table 3. Organogenesis period: embryonic events/stages of Betta splendens observed from 15 until 38 HPF of the experiment

\begin{tabular}{lcc}
\hline Stages/Events & HPF & HGPF ${ }^{\circ} \mathrm{C}$ \\
\hline Embryo differentiation & 15.0 & 420.0 \\
Primordial optic differentiation & 15.5 & 434.0 \\
Evident primordial optic & 17.0 & 476.0 \\
Appearing of somites (8-10) & 17.5 & 490.0 \\
10 well visible somites & 19.0 & 532.0 \\
Somites and beginning of optical vesicle & 19.5 & 546.0 \\
Somites in "V" (15 somites) & 21.0 & 588.0 \\
Caudal button; beginning of hyaline membrane formation & 22.0 & 616.0 \\
Structure development & 23.5 & 658.0 \\
First observation chondrocranium & 24.0 & 672.0 \\
First observation of heartbeats in three embryos 60/min & 25.0 & 700.0 \\
Heartbeats of three embryos 120; 120; 108 average: 16/min & 26.5 & 742.0 \\
Circulation & 27.0 & 756.0 \\
Circulation, tail movement (muscle contraction) & 27.5 & 770.0 \\
Eyes movements, crystaline & 28.5 & 798.0 \\
Increase of structures size & 30.0 & 840.0 \\
Increase of melanophores & 30.5 & 854.0 \\
Observation of adhesive gland & 32.5 & 910.0 \\
Melanofores with dendritic aspect & 34.0 & 931.6 \\
Structure growth & 36.0 & 1008.0 \\
Beginning of hatching & 38.0 & 1064.0 \\
\hline
\end{tabular}

*Hours-post-fertilization (HPF); *Hours-degrees-post-fertilization (HGPF).

Oil drops presented the same distribution and aggregation behavior observed from eggs recently fecundated of Melanotaenia fluviatilis. During development stages, the oil drops were grouped at the opposite region of blastoderm into the vesicle (REID \& HOLDWAY, 1995; MIHALACHE et al., 2011).

During cleavage period, the first cleavage with 2 cells occurred at 1.5 HPF and 42.0 HGPF. After 90 minutes, two blastomeres were already perfectly visible (Figure 2A).

Second cleavage fold with 4 cells observed at 2.00 HPF and 56.0 HGPF, was formed transversely to the first dividing in two blastomeres. Blastoderm in this phase was formed by four blastomeres, disposed in a $2 \times 2$ arrangement upon vitelline vesicle.
Third cleavage fold with 8 cells observed at 2.5 HPF and 70.0 HGPF were formed vertically to the second fold of the previous phase with 4 blastomeres. Blastoderm in this phase was formed by eight blastomeres, disposed in a $4 \times 2$ arrangemend upon vitelline vesicle (Figure $2 \mathrm{~B}$ ).

Fourth cleavage fold with 16 cells observed at $30 \mathrm{HPF}$ and 84.0 HGPF was formed transversely to the third cleavage. The division was completed when 16 blastomeres were formed, that could be observed in a $4 \times 4$ arrangement (Figure 2C)

Fifth cleavage fold with 32 cells occurred at 3.5 HPF and 98.0 HGPF forming a line of blastomeres, organized in the blastoderm with 32 blastomeres 
Rev. Bras. Saúde Prod. Anim., Salvador, v.13, n.3, p.xxx-xxx jul./set., 2012 http://www.rbspa.ufba.br ISSN 15199940

within a simple layer, in a $4 \times 8$ arrangement.

Blastoderm division with 64 cells was observed at 4.0 HPF and 112.0 HGPF. Each blastomere performed a latitudinal division and generated a new layer of blastomeres. The oil drop was not dislocated to the vegetative pole periphery, the opposite region from the blastoderm (Figure 2D).
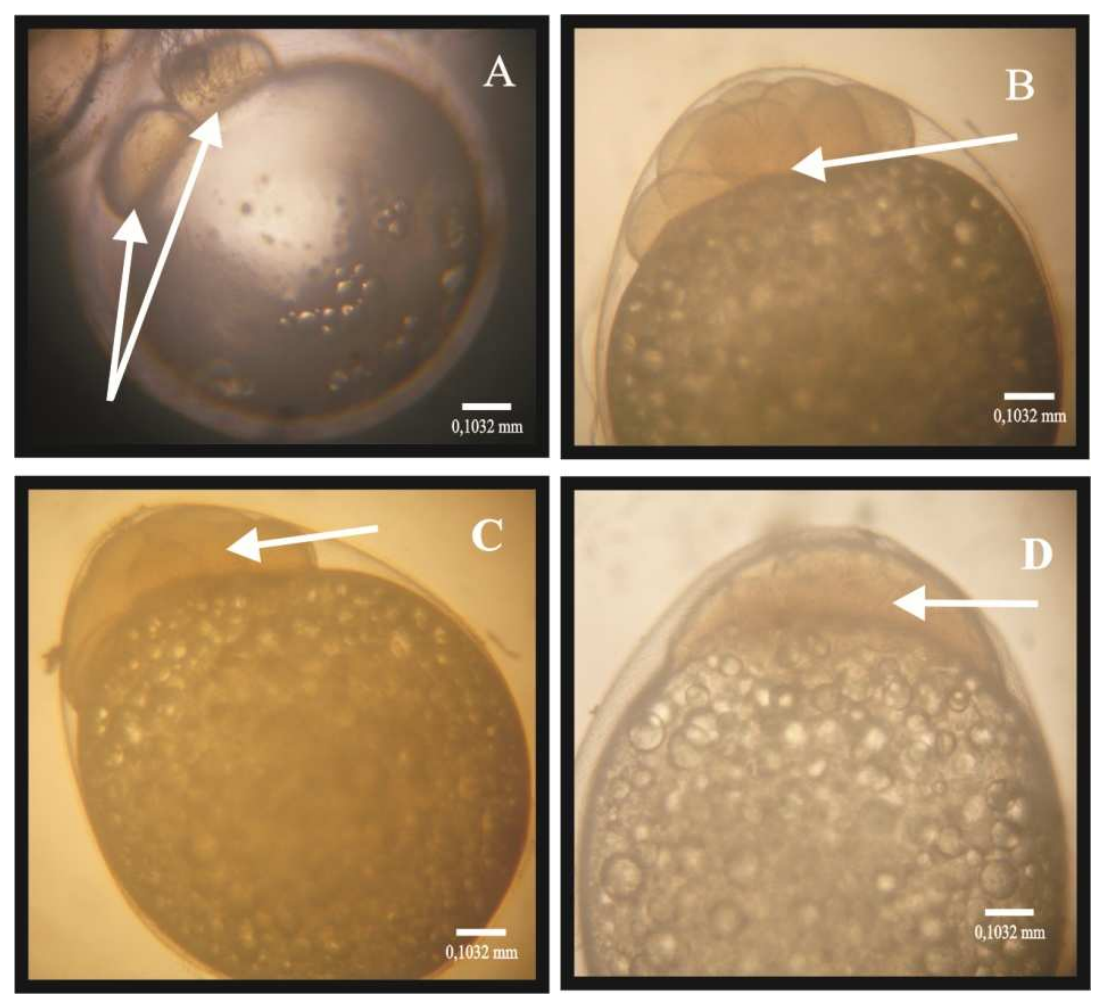

Figure 2. Embryonic development of $B$. splendens during the cleavage period: (A) $0.5 \mathrm{HPF}$ with 2 blastomeres; (B) 2.5 HPF and with 8 blastomeres; (C) $3.0 \mathrm{HPF}$; (D) 4.0 HPF, Blastula

The spherical phase started at 7.5 HPF and 210.0 HGPF. The larger axis and smaller axis presented similar values at this moment and the embryo acquired the spherical form. The limits between the blastoderm and vitelline vesicle became continuous (Figure 3).

During gastrula period epiboly, the evolution of blastoderm upon vitelline vesicle, began at $8.5 \mathrm{HPF}$ and 238.0 HGPF. Initially, a little dome is formed by blastoderm, covering around 10\% over the vitelline vesicle. Blastoderm progression was identified and happened at the end of epiboly in a rate of $20 \%$ /hour in average. Reid \& Holdway (1995) reported that gastrula phase of $M$. fluviatilis began around 13.0 HPF and Humphrey et al. (2003) reported for M. s. splendida around 10.0 HPF. Ferreira et al. (2009) studied Astyanax bimaculatus and reported the beginning of gastrula phase at 2.0 HPF that lasted until approximately $3.5 \mathrm{HPF}$ at $28^{\circ} \mathrm{C}$. Nakatani et al. (2001) observed the beginning of gastrula phase of cultivated Brazilian rheophile fish and reported lower values than observed for Betta splendens. 

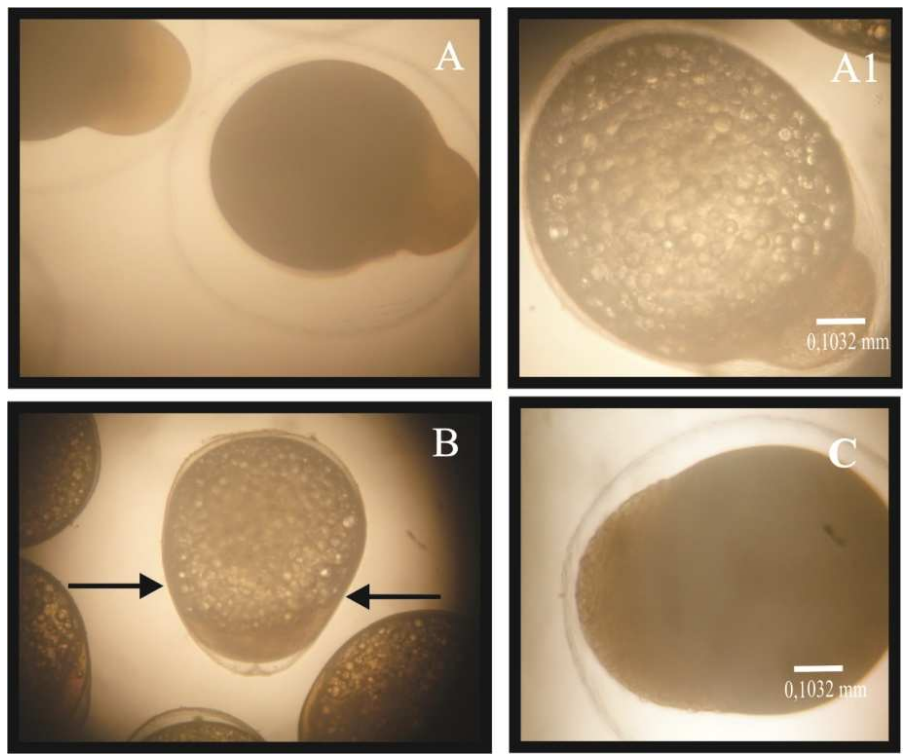

Figure 3. Embryonic development of $B$. splendens during the blastula period: (A) 5.0-6.5 HPF and (A1) 256-cells; (B) 7.0 HPF oval stage; (C) 7.5 HPF spherical stage

Embryo covered around $50 \%$ of vitelline vesicle by the evolution of blastoderm at 11.0 HPF and $308 \mathrm{HGPF}$. Embryo continued the development of existing structures and yolk reduced only a little (Figure 4A). Blastoderm cover continued to evolve upon vitelline vesicle and reached $70 \%$ at $13.0 \mathrm{HPF}$ and 364.0 HGPF. Formation of embryonic axis was not observed during the evolution of blastoderm margins (Figure 4B). Reid \& Holdwday (1995) mentioned that the formation of embryonic axis in $M$. fluviatilis development happens during the blastoderm evolution. According to Humphrey et al. (2003) during the embryonic development of $M . s$. splendida, at gastrula stage $70 \%$, the differentiation of the embryonic axis and the germ ring was verified. Blastoderm covered $80 \%$ over vitelline vesicle (gastrula stage $80 \%$ ) at $14 \mathrm{HPF}$ and $392 \mathrm{HGPF}$, and at this moment blastoderm margins generated the blastopore.
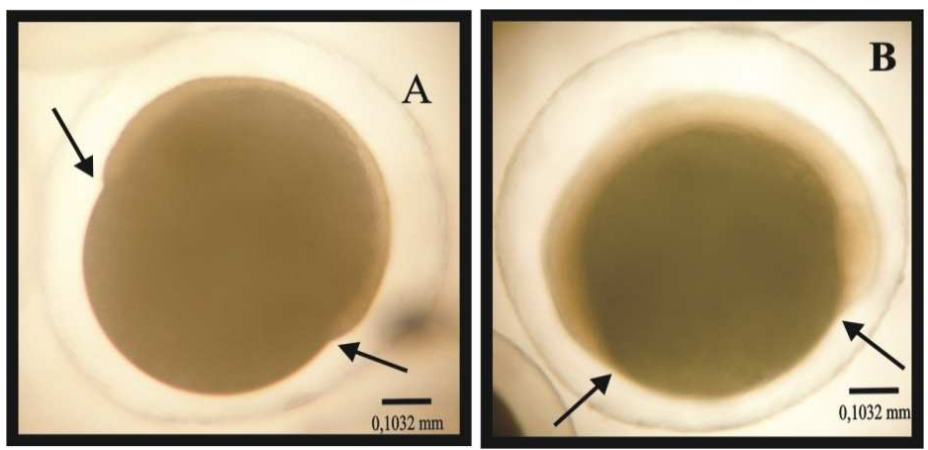

Figure 4. Embryonic development of B.splendens during the gastrula period: (A) $11.0 \mathrm{HPF}$, gastrula $50 \%$ and (B) 13.0 HPF, gastrula 70\% 
Blastopore closure happened at 14.5 HPF and 406.0 HGPF, when blastoderm margins met and merged covering $100 \%$ of the yolk vesicle. This closure was mentioned in M. nigrans and $M$. s. inornata near 18.0 HPF (REID \& HOLDWAY, 1995) and in M. s. splendid 12.5 HPF (HUMPHREY et al., 2003). A faster embryonic development could be perceived in Brazilian rheophile fish. As example, Brycon orbygnianus embryos showed blastopore closure at $6.5 \mathrm{HPF}$ (REYNALTE-TATAJE et al., 2004) and Brycon insignis at 5.5 HPF and 161.0 HGPF (SOUZA et al., 2004). Ferreira et al. (2009) reported blastopore closure of A. bimaculatus at 5.5 HPF and G. incisus at $11.8 \mathrm{HPF}$, respectively.

Embryonic axis of $B$. splendens can be observed at 15.0 HPF and 420.0 HGPF, formation began over the embryonic shield of yolk vesicle (Figure 5A). Ferreira et al. (2009) reported the differentiation of embryonic axis at 12.3 HPF for $G$. incisus, whereas Reid \& Holdway (1995) observed at 15.0 HPF during the gastrula development of $M$. fluviatilis. Humphrey et al. (2003) reported the same process around 10.0 HPF for M. splendid, also during gastrula period (gastrule stage 30\%). Probably, the differentiation of embryonic axis of $B$. splendens happened in earlier phases but it was difficult to observe.

The primordial optic could be observed at 15.5 HPF and 434.0 HGPF. This structure rises from the cephalic region of the embryo as an evagination of a pair of rudimentary optical vesicles (Figure 5B).

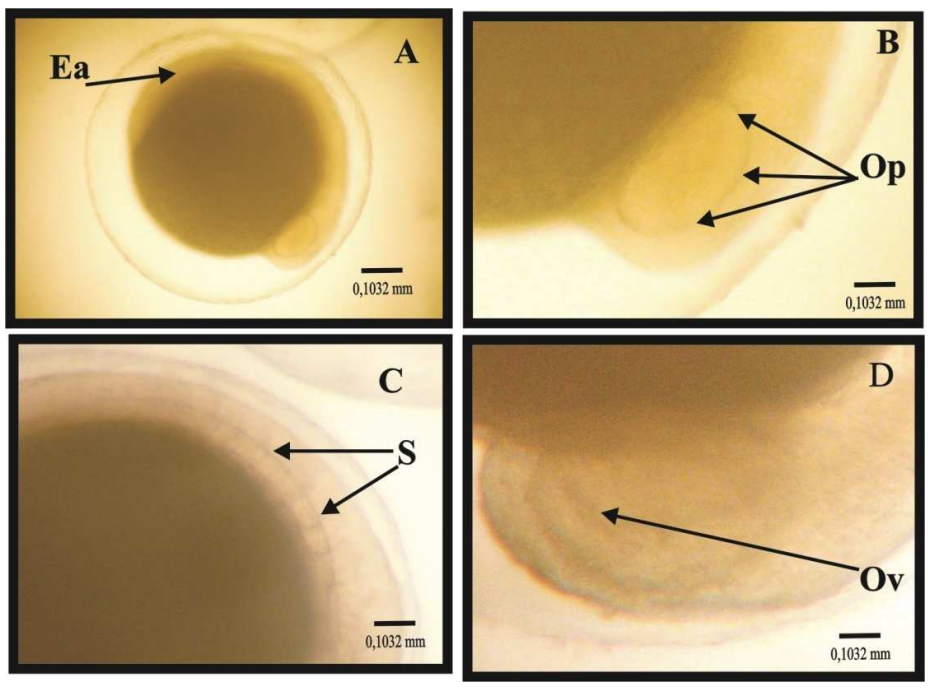

Figure 5. Embryonic development of $B$. splendens during the organogenesis period: (A) embryonic axis (Ea) 15.0 HPF; and (B) primordial optic (Po) 15.5 HPF; (C) 10 somites (S) and (D) beginning of optical vesicle (Ov) 19.4 HPF

About eight rudimentary somites with elliptical form, at the embryo median region, were observed at $18.5 \mathrm{HPF}$ and 490.0 HGPF. The optical vesicle developed progressively on the head region (Figure 5C). Notochord was also identified in this stage along the embryo axis. Reynalte-Tataje et al. (2001) reported that the notochord of Oryzias latipes assembles from epithelial folding, consisting of cells with numerous vacuoles, connected and involved by a 
complex liner, formed by an internal membrane secreted by the cells of the notochord epithelium. This membrane is covered with a dense fibrous sheath, composed of collagen fibers, an external elastic layer (elastic fibers) and a superficial layer of connective tissue sheath with extracellular matrix of collagen deposited by mesenchimal fibroblasts.

Visualization of approximately 10 somites and the higher development of optical vesicle occurred at 19.5 HPF and 546 HGPF. Retina differentiation on primordial optic was observed at this phase, beginning the differentiation to optical vesicle (Figure 5D). This differentiation was observed by Ferreira et al. (2009) for G. inscisus at 23.0 HPF. Formation of chondrocranium was observed at 24.0 HPF and 672.0 HGPF. Cartilaginous cranial structure of the embryo could be visualized at this stage on the cephalic region, originating the cranium base that will sustain the brain. This structure forms a closed box and does not ossify (Figures 6A and 6B). The same structures at the similar moments could be observed by Fujimoto et al. (2006) for $M$. anguillicaudatus species.

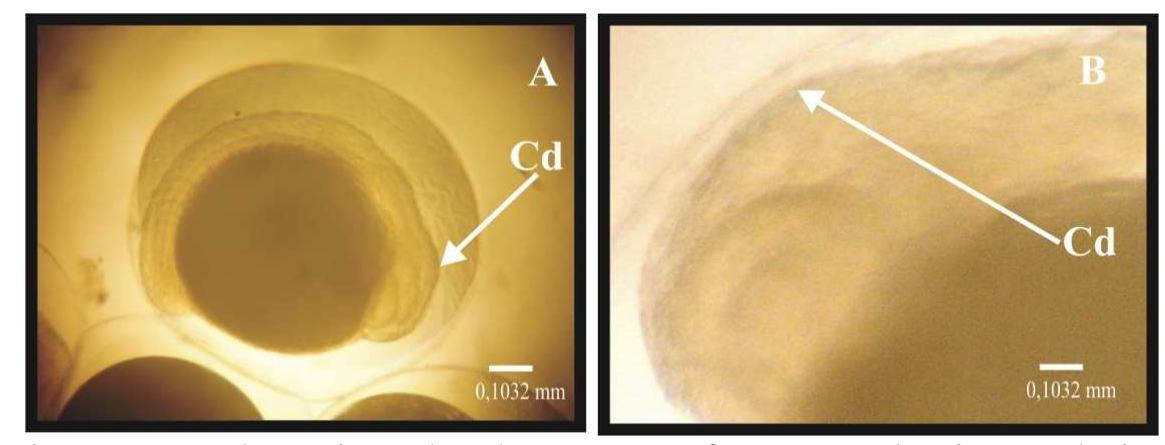

Figure 6. Embryonic development of B. splendens during organogenesis period: (A) and (B) observation of chondrocranium $(\mathrm{Cd}) 24.0 \mathrm{HPF}$
Heart beat began at 25.0 HPF and 742.0 HGPF (Figure 7A). Analysed individuals presented initially 60 heart beats/minute in average. Reid \& Holdway (1995) reported 72 heart beats/minute at $46.0 \mathrm{HPF}$ for $M$. fluviatilis. The main structures of the embryonic heart were observed on the axial vein region of mesoderm and the beginning of peristaltic movements slowly ensured blood circulation. Crowley \& Ivantsoff (1982) reported the beginning of heart beat of $M$. nigrans and $M$. s. inornata at $47 \mathrm{HPF}$ and $25^{\circ} \mathrm{C}$, whereas Ferreira et al. (2009) observed 50.44 heart beats/minute, in average, at 27.0 HPF for G. incisus embryos.

Blood circulation on vitelline vesicle was observed at 27.0 $\mathrm{HPF}$ and 756.0 HGPF. This circulation began over the embryonic axis and presented higher blood flow speed, with 120 heart beats/minute. Also, at the same moment, the embryonic axial vein was divided in two branches. Then, the new vein and branches developed upon vitelline vesicle ensuring blood circulation over the peripheral region of yolk. Ferreira et al. (2009) verified blood circulation for $G$. incisus at 34.0 HPF, whereas Humphrey et al. (2003) 
mentioned the beginning at $30.5 \mathrm{HPF}$ for M. s. splendid and Reid \& Holdway (1995) at approximately 50.0 HPF for M. fluviatilis.

Embryo began to move at 27.5 HPF and $770.0 \mathrm{HGPF}$. The beginning of muscle contractions presented low frequency on repetition of spasms, initially on tail. The somites were already disposed in "V" formation and the button tail was free. B. insignis (Souza, 2004) and $G$. incisus (FERREIRA et al., 2009) presented those movements at 35.0 HPF.

Crystalline pigmentation and retina pigmentation presented higher development after 28.5 $\mathrm{HPF}$ and 798 HGPF, also when the eyes started to move.

Melanophores raised randomly along embryonic axis and passed to the vitelline vesicle at 34.0 $\mathrm{HPF}$ and 931.6 HGPF. Initially, melanophores are dendritic cells with several branches and that was also reported by Ferreira et al. (2009) and Reid \& Holdway (1995) who verified those movements at 28.0 HPF for G. incisus and M. fluviatilis, respectively.

The pigmentation of circulation system was observed for the first time at 36.0 HPF and 1008.0 HGPF. Blood begins colouration by passing through uncoloured to reddish, with the heart presenting two chambers working in antagonistic movements of systole and diastole, representing atrium and ventricle. Ferreira et al. (2009) mentioned this moment at 59.75 HPF for $G$. incisus development. Luz \& Zaniboni Filho (2002) verified this pigmentation a little before Pimedolus maculates larvae hatching, at 21.20 HPF.

Embryo hatching began from $38.0 \mathrm{HPF}$ and 1064.0 HGPF until 40.0 HPF and 1120 HGPF (Figure 7B). This period of embryonic development can be considered normal to Betta.
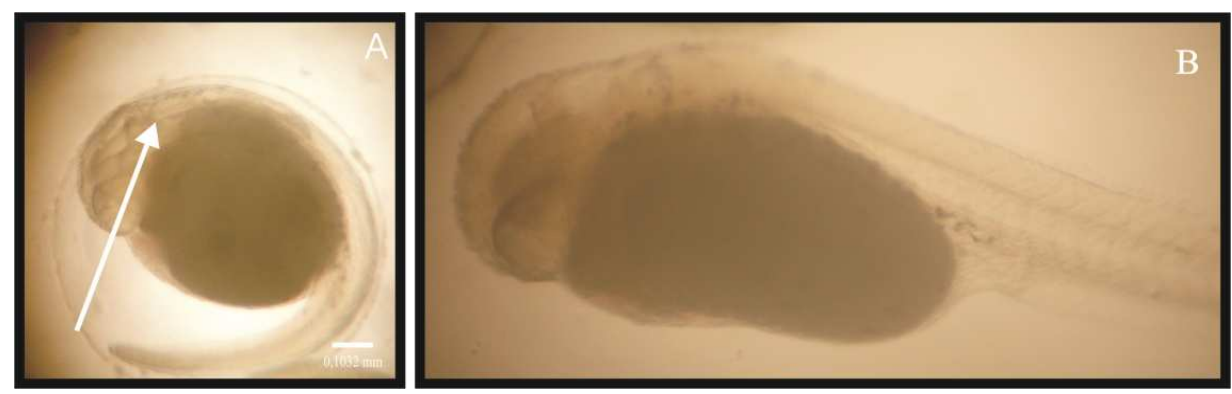

Figure 7. Embryonic development of $B$. splendens during organogenesis period: (A) Heart 25.0 HPF; (B) embryo post-hatching 38.0 HPF

Animals from Melanotaenia genus present values between 6 and 7 days of embryonic development in literature as a normal development period (HUMPHREY et al., 2003; REID \& HOLDWAY, 1995; FERREIRA et al., 2009). Hatching period of M. fluviatilis was between 7 and 9 days, whereas of M. s. splendidia, between 4 and 8 days of embryonic development. Arenzon et al. (2002), mentioned that M. s. australis, $M . \quad s$. inornata and $M$. niigrans (Melanotaenia genus species), presented embryonic period of 4.5 days at $26^{\circ} \mathrm{C}$ (Humphrey et al., 2003).

Larvae hatched through corium rupture in a very fast way, similar to the observed by Ferreira et al. (2009) to the 
Rev. Bras. Saúde Prod. Anim., Salvador, v.13, n.3, p.xxx-xxx jul./set., 2012 http://www.rbspa.ufba.br ISSN 15199940

Melanotaenia genus. The newly hatched larvae were active with swimming ability, which demonstrates a morphophysiological normality of these animals. After hatching 11 larvae were measured and presented total length of $0.6405 \pm$ $0.02 \mathrm{~mm}$ and total height of $0.1657 \pm$ $0.02 \mathrm{~mm}$ in average.

Newly hatched larvae contained a mean residual yolk of $0.01935 \mathrm{~mm}^{3} \pm 0.005$. Oil drops could be observed in this vitelline residue and this was not described by any author in consulted literature.

Heart rate of newly hatched $B$. splendens larvae was 156 per minute. During the progressive development of circulatory system and, consequently, the increasing heart rate, a decrease of heart rate could be observed at nocturnal period that returned to normal levels by the morning. These facts suggest a specific relation with circadian rhythm or a physiological response to period of darkness due to the stress caused by periods of light.

Cleavage period of Betta splendens begins with formation of animal pole at 1.5 HPF and 42 HGPF. Blastula period began at 4.5 HPF and 126 HGPF and the blastopore closure happened at 14.5 HPF and 406.0 HGPF, when blastoderm margins met and merged covering $100 \%$ of yolk vesicle.

Organogenesis period began at $15 \mathrm{HPF}$ and $420 \mathrm{HGPF}$ with the differentiation of the embryo that culminated with the hatching of embryos, from 38.0 HPF and 1064.0 HGPF until 40.0 HPF and 1120.0 HGPF.

Thus, description of embryonic development can contribute for reproduction techniques in laboratory, giving information to technicians and producers to achieve better results in their ornamental fishes spawning.

\section{REFERENCES}

ARENZON, A.; LEMOS, C.A.; BOHRER, M.B.C. The influence of temperature on the embryonic development of the annual fish Cynopoecilus melanotaenia (Cyprinodontiformes). Brazilian Journal of Biology, v.62, n.4B, p.743747, 2002.

BLAXTER, J. H. S. Pattern and variety in development. In: HOAR, W.S., RANDALL, D.J. Fish physiology. San Diego: Academic Press, 1998. v.11, p.158.

CHAPMAN, F.A.; FITZ-COY, S.A.; THUNBERG, E.M. United States of America trade in ornamental fish. Journal of the World Aquaculture Society, v.28, n.1, p.1-10, 1997.

CROWLEY, L.E.L.M.; IVANTSOFF, W. Reproduction and early life stages in two species of australian rainbowfishes, melanotaenia nigrans and melanotaenia splendida inornata (Castelnau).

Australian Zoologist, v.21, p.85-95, 1982.

FARIA, P.M.C.; CREPALDI, D.V.; TEIXEIRA, E.A.; RIBEIRO, L.P.; SOUZA, A.B.; CARVALHO, D.C.; MELO, D.C.; SALIBA, E.O.S. Criação, manejo e reprodução do peixe Betta splendens. Revista Brasileira de Reprodução Animal, v.30, p.134-149, 2006.

FERREIRA, A.V.; VIDAL JUNIOR, M.V.; ANDRADE, D.R.; YASUI, G.S.; MENDONÇA, P.P.; MATTOS, D.C.

Consumo de vitelo durante o desenvolvimento embrionário de Melanotênia-maçã (Glossolepis incisus). Ciência Animal Brasileira, v.10, p.721-729, 2009. 
Rev. Bras. Saúde Prod. Anim., Salvador, v.13, n.3, p.xxx-xxx jul./set., 2012 http://www.rbspa.ufba.br ISSN 15199940

FUJIMOTO, T.; KATAOKA, T.; OTANI, S.; SAITO, T.; AITA, T.; YAMAHA, E.; ARAI, K. Embryonic states from cleavage to gastrula in the loach Misgurnus anguillicaudatus. Zoological Society of Japan, v.21. p.747-755, 2004.

FUJIMOTO, T.; KATAOKA, T.; SAKAKO, S.; SAITO, T.; YAMAHA, E.; ARAI, K. Developmental stages and germ cell lineage of de loach (Misgurnus anguillicaudatus).

Zoological Society of Japan, v.23. p.977-989, 2006.

GROTH, W.O. Embryology of the siamese fighting fish Betta splendens. 1970. 44p. Thesis (Master of Arts) The School of Graduate Studies Drake University, Des Moines.

HANIFFA, M.A.P.S.; BENZIGER A.; JESU AROCKIARAJ, A.;

NAGARAJAN, M.; SIBY, P. Breeding behaviour and embryonic development of koi carp (Cyprinus carpio).

Taiwania, v.52. n.1, p.93-99, 2007.

HUMPHREY, C.; KLUMPP, D. W.; PEARSON, R. Early development and growth of the east rainbowfish, Melanotaenia splendida splendida. Morphogenesis and ontogeny. Marine and Freshwater Research, v.53,p.1725, 2003.

KOVAC, V.; COOP, G. H. Prelude: looking at early development of fishes. Environmental Biology of Fishes, v.56, p.7-14, 1999.

LUZ, R. K.; ZANIBONI FILHO, E. Larvicultura do Mandi-amarelo Pimelodus maculatus Lacépède, em diferentes densidades de estocagem nos primeiros dias de vida. Revista Brasileira de Zootecnia, v.31, n.2, p.560-565, 2002.
MACIEL, C.M.R.R.; LANNA, E.A.T.; MACIEL JUNIOR, A.; DONZELE, J.L.; NEVES, C.A.; MENIN, E. Morphological and behavioral development of the piracanjuba larvae. Brazilian Journal of Animal Science, v.39, p.961-970, 2010.

MIHALACHE, A.; OPREA, L.; GRECU, I.; CRISTEA, V.C.

BADALAN , I.; ENACHE, S. Artificial reproduction and embryonic development of the japanese ornamental carp (Cyprinus carpio Linnaeus, 1758). Journal of Environmental Protection and Ecology, v.12, n.4, p.1835-1839, 2011.

NAKATANI, H.K.; AGOSTINHO, A.A.; BAUMGARTNER, G.; BIALETZKI, A.; SANCHES, P.V.; MAKRAKIS, M.C.; PAVANELLI, C.S. Ovos e larvas de peixes de água doce: desenvolvimento e manual de identificação. Maringá: Universidade Estadual de Maringá, 2001. 378p.

PAMPLONA, G.C.; LIMA, J.W.O.; CUNHA, J.C.L. Evaluation of the impact on Aedes aegypti infestation in cement tanks of the municipal district of Canindé, Ceará, Brazil after using the Betta splendens fish as an alternative biological control. Revista Sociedade Brasileira Medicina Tropical, v.37, p.400-404, 2004.

PEREZ-CASANOVA, J.C.; MURRAY, H.M.; GALLANT, J.W.; ROSS, N.W.; DOUGLAS, S.E.; JOHNSON, S.C. Development of the digestive capacity in larvae of haddock (Melanogrammus aeglefinus) and Atlantic cod (Gadus morhua). Aquaculture, v.251, p.377401, 2006. 
Rev. Bras. Saúde Prod. Anim., Salvador, v.13, n.3, p.xxx-xxx jul./set., 2012 http://www.rbspa.ufba.br ISSN 15199940

REID, H.P.; HOLDWAY, D.A. Early development of the Australian crimsonspotted rainbowfish, Melanotaenia fluviatilis (Pisces: Melanotaeniidae). Marine and

Freshwater Research, v.46, p.475-480, 1995.

REYNALTE-TATAJE, D.A.; ZANIBONI FILHO, E.; ESQUIVEL, J.R. Embryonic and larval development of piracanjuba Brycon orbignyanus (pisces, bryconidae). Acta

Scientiarum, v.26, p.67-71, 2004.

REYNALTE-TATAJE, D.R.; ZANIBONI-FILHO, E.; MUELBERT, B. Stages of the embryonic development of the piavuçu Leporinus macrocephalus. Acta Scientiarum, v.23, p.823-827, 2001.

SOUZA, G.; ANDRADE, D.R.; VIDAL JÚNIOR, M.V.; YASUI, G.S. Desenvolvimento embrionário da piabanha Brycon insignis. In: CONGRESSO DA SOCIEDADE BRASILEIRA DE AQUICULTURA E BIOLOGIA AQUÁTICA, 1., 2004, Vitória, ES. Anais... Vitória,ES: AQUABIO. v.1, p.208-208, 2004.
TONINI, W.C.T.; POLESE, M.F.; ABREU, M.L.C.; MATTOS, D.C.; VIDAL JÚNIOR, M.V.; ANDRADE, D.R. Digestibilidade aparente de alimentos proteicos e energéticos para Tricogaster leeri. Revista Brasileira de Saúde e Produção Animal [Online], v.13, p.569-577, 2012.

VERBEEK, P.; IWAMOTO T.; MURAKAMI, N. Differences in aggression between wild-type and domesticated fighting fish are context dependent. Animal Behaviour, v.73, n.73, p.75-83, 2007.

Data de recebimento: 08/01/2012

Data de aprovação: 04/09/2012 